\title{
Inclusive Worship and Group Liturgical Action
}

\author{
Joshua Cockayne, University of St. Andrews \\ jlc22@st-andrews.ac.uk
}

\begin{abstract}
In this article, I consider how recent work on the philosophy of group-agency and shared-agency can help us to understand what it is for a church to act in worship. I argue that to assess a model's suitability for providing such an account, we must consider how well it handles cases of non-paradigm participants, such as those with ASD and young infants. I suggest that whilst a shared-agency model helps to clarify how individuals coordinate actions in cases of reading or singing liturgy, it does not handle non-paradigm cases well and so cannot be considered a suitable model of group liturgical action. Instead, I suggest that a model of group-agency, in which a plurality of action types can contribute to the actions of a group as a whole, is better suited to explaining a church's actions in worship.
\end{abstract}

\section{Introduction}

Every week, in churches all over the world, congregations thank God together, confess their sins together, and offer prayers together. Many of the liturgies used in corporate worship use the pronoun 'we' to signify that the congregation, together, participates in worship. In the Church of England's Common Worship, for instance, the congregation confess their sins together ('we have sinned against you and against our neighbour in thought and word and deed' Common Worship, Holy Communion, Prayers of Penitence)), they thank and praise God together ('we thank you for feeding us with the body and blood of your Son Jesus Christ' (Common Worship, Holy Communion, Prayer After Communion)), and they share in the breaking of bread together ('Though we are many, we are one body, because we all share in one bread' (Common Worship, Holy Communion, Breaking of the Bread)). Liturgical worship is an importantly corporate activity. ${ }^{1}$

Indeed, many theological writers have been keen to stress that it is not the individual members of churches who worship God, but, rather, it is the assembled group of people who

\footnotetext{
${ }^{1}$ I will use the term 'liturgical worship' throughout this paper. As I will use the term, it simply refers to any worship which is scripted. As Wolterstorff notes, even in Church traditions in which no liturgical texts or spoken forms of liturgy are used, there are scripted actions which the congregation performs to engage with $\operatorname{God}(2015,9)$.
} 
worship God together as a gathered church. Likewise, when worship is discussed in Scripture, the subject is, more often than not, the community of worshippers and not the individual worshipper. This understanding of worship provides us with a philosophical problem: How can a church which is composed of many individual members be considered an agent in its own right?

To answer this question, I draw from the philosophical literature on group action. It is not unusual, in everyday speech, to talk of groups as if they were capable of believing and acting in ways irreducible to the actions and beliefs of the individual group members. For example, we speak of an orchestra's elegant performance, of a financial corporation's greed, and of a newspaper's biased views. The philosophy of group action attempts to make sense of how groups, and not just individuals, can be considered agents capable of acting. I argue that there is much in this literature which can inform and make sense of how the church can engage in worship.

I outline two models of group liturgical action drawn from this literature to consider how we might best account for a church's actions in worship. The first model draws from sharedagency accounts (such as that defended by John Searle $(1990,2010)$ ), which seek to explain how individual intentions can be coordinated in group action. The second model draws from groupagency accounts (such as that defended by Christian List and Philip Petit (2010)), which seek to explain how a group constituted by individuals could be structured in such a way that it might be considered an agent in its own right.

To establish which model is better suited to understanding a church's worship, I then consider how each model handles non-paradigm participants in worship, such as those with ASD (Autism Spectrum Disorder) and very young infants. I maintain that the best model for understanding the church's actions in worship will provide an inclusive account of how participants can engage in and contribute to the church's worship. I argue that a group-agency model is better suited to giving an account of what it is for a church to act in worship. Whilst a shared-agency model can help to explain some kinds of group liturgical action (such as coordinated singing and reading of a liturgical script), such an account has its limits since it assumes only neuro-typical individuals are engaged in liturgical action and it excludes those who do not have the capacity to engage in complex coordinated action. I argue that a model of Church action which can account for a pluralistic and inclusive participation in worship is 
preferable. Since the group-agency model allows for such participation, it should be preferred as a model of what it is for a church to act in worship. ${ }^{2}$

\section{A theological position, a philosophical problem}

To begin with, I will lay out the issues involved, theologically, before considering how philosophical work on group action might help us to understand these issues more clearly.

Throughout Scripture, worship is frequently described in reference to communities and groups of individuals, and much less frequently, as an act performed by individuals alone. ${ }^{3}$ Indeed, the vast majority of the practices and rituals associated with worship which are described in Scripture are not performed by individuals, but, rather, by communities. Dru Johnson (2016), in his discussion of ritual epistemology in Scripture, talks of the 'social process' $(2016,246)$ of coming to know through such rituals. As Johnson notes, the rituals of Scripture lack the individualistic, egalitarian sensibilities of some modern theological thought. That is, the worship rituals in the Hebrew Bible do not give an equal role to all participants; Johnson notes that men, women, children and priests all had different roles to play in the practice of rituals. The reason for this, Johnson argues, is that it is the community that engages in these practices, and not just the individual. Thus, he thinks, 'because different roles in Israelite society will necessarily dispose persons to be variously discerning, they must rely upon each other in order to know well' (2016, 246).

This emphasis on community is not found only in the rituals of the Hebrew Bible, however. We can see this emphasis on community in the New Testament, particularly with reference to the community of the Christian Church (ekelèsia, literally_ 'called out of'). In 1 Corinthians, for instance, Paul spends a considerable time resolving issues relating to the worship of the early Church. Yet, it is notable that, throughout these discussions, although Paul speaks to individuals about their specific role in worship, his concern is to address the

\footnotetext{
${ }^{2}$ As I will argue, this is not to say that a shared-agency model is, therefore, redundant, but just that it has its limits.

${ }^{3}$ See: Exodus 3:13, 7:16, 9:1, 33:10; Joshua 22:27; 1 Samuel 1:19; 2 Kings 17:32; 2 Chronicles 7:3, 29:28-30: Nehemiah 8:6, 9:3; Psalm 55:14, 95:6, 102:22; Jeremiah 26:2; Ezekiel 46:9; Matthew 2:11, 14:33, 28:17; Luke 1:10, 24:52; John 4:24; Acts 13:2; Romans 12:1; 1 Corinthians 14:26; Hebrews 12:28, Revelation 7:11, 11:16, 19:4.
} 
community of worshippers. ${ }^{4}$ We can see this most strikingly as his thought reaches its climax in his use of the metaphor of the body of Christ in chapter 12. Paul writes that

the body does not consist of one member but of many. If the foot would say, "Because I am not a hand, I do not belong to the body," that would not make it any less a part of the body. And if the ear would say, "Because I am not an eye, I do not belong to the body," that would not make it any less a part of the body. If the whole body were an eye, where would the hearing be? If the whole body were hearing, where would the sense of smell be? But as it is, God arranged the members in the body, each one of them, as he chose. If all were a single member, where would the body be? As it is, there are many members, yet one body. The eye cannot say to the hand, "I have no need of you," nor again the head to the feet, "I have no need of you." On the contrary, the members of the body that seem to be weaker are indispensable, and those members of the body that we think less honourable we clothe with greater honour, and our less respectable members are treated with greater respect; whereas our more respectable members do not need this. But God has so arranged the body, giving the greater honour to the inferior member, that there may be no dissension within the body, but the members may have the same care for one another. If one member suffers, all suffer together with it; if one member is honoured, all rejoice together with it. (1 Corinthians 12:14-26). ${ }^{5}$

\footnotetext{
${ }^{4}$ Note that sometimes the emphasis on the corporate nature of worship in the New Testament is overlooked due to the ambiguity of the second-person plural pronoun in English. Take the following verse, for instance, 'Or do you not know that your body is a temple of the Holy Spirit' (1 Corinthians 6:19). Read in English, this looks to be addressing the singular second-personal, yet, in Greek, the pronoun used is the plural second-person.

${ }^{5}$ This is not the only place in which we find such an analogy. The metaphor of the body and its parts is used in a number of places (Colossians 1: 18-20, Colossians 3:12-17, Romans 12:3-8), so also is the model of the temple and its bricks (2 Corinthians 6:14-18, 1 Corinthians 6:18-20, 1 Corinthians 3:10-17), the household and its stones (1 Timothy 3:14-15, Ephesians 2:11-20, 1 Peter 2:3-8), the field and its workers (1 Corinthians 3:5-9), and a nation and its citizens (1 Peter 2:9-10, Matthew 5:13-16, Hebrews 11:8-16) in explaining the relationship between individuals and the Church.
} 
This passage is striking for a number of reasons-we see Paul stress the importance of the community of the Church in relating to God and the need to be united together. ${ }^{6}$ However, we also see that this cannot be any community — the Church must be a radically inclusive community; both the weak and strong, the seemingly dispensable and indispensable, the seemingly honourable and dishonourable, are to be regarded as vital parts of the same collective whole and vital parts of the Church's worship. ${ }^{7}$

The theological position outlined above, which claims that worship is primarily performed by groups and not just individuals, provides a difficult philosophical problem: ${ }^{8}$ While

\footnotetext{
${ }^{6}$ We can find this emphasis on the corporate nature of worship in many places in the theological literature. For instance, Evelyn Underhill writes,
}

The worshipping life of the Christian whilst profoundly personal, is essentially that of a person who is also a member of a group...The Christian as such cannot fulfil his spiritual obligations in solitude. He forms part of a social and spiritual complex with a new relation to God; an organism which is quickened and united by... [the] Spirit. (1936, $83)$.

As Underhill goes on to note, a Christian's relationship to God must be understood through her relationship as a member of a group - the body of Christ. To understand the nature and purpose of liturgy, according to Underhill, we need to see liturgical action as an example of 'joint action' $(1936,99)$, which is, she maintains, the reason why some agreed pattern of liturgy is so vital for Christian worship. Similarly, Alexander Schmemann (1966), writing in the Eastern Orthodox tradition, writes that, "the division in principle between "corporate" and "private" worship must be discarded. The purpose of worship is to constitute the Church, precisely to bring what is "private" into the new life, to transform it into what belongs to the Church' $(1966,24)$.

${ }^{7}$ Barbara Newman (2011), in her writing on inclusivity and disability in the Church, takes these words of Paul's to provide a challenge for the contemporary Church in how it treats those with ASD. She writes that 'our weaknesses and needs are part of God's design so that others may minister to us. We truly were created to need one another' $(2011,16)$. As we will see, this issue of inclusivity will act as a kind of litmus test for the models of church worship I later consider.

${ }^{8} \mathrm{I}$ am not claiming that there can be no individual worship, but, rather, that individual worship must be understood in its relation to the Church as a whole. This will become clear in the final two sections of the paper. With thanks to an anonymous referee for raising this issue. 
it is clear that the individual members of a church can be agents who use their minds and powers to worship God, it is entirely unclear how a gathered church, which has neither a mind nor powers over and above the minds and powers of its members, can be an agent which worships God. This is the philosophical problem that the foregoing theology of worship gives rise to, and what the remainder of this paper is devoted to addressing.

However, before we can give a response this question, greater clarity is needed. If we are to give an account of how individuals can be related to a gathered church in worship, we must first specify just what a church is. ' To complicate matters, the term 'church' is used in a diversity of ways. For instance, in his introduction to Anglican Ecclesiology, Paul Avis gives four definitions of 'church' (Church catholic, particular Church traditions, Church diocese, and Church parishes), all of which he regards as groups which are engaged in worship in some way. To simplify matters somewhat, here I will refer to two uses of 'church': (i) the whole Church, which is constituted (at least) by individual church congregations, which are globally distinct, historically separated and theologically diverse, and, (ii) a gathered church, which is constituted by individuals who are part of a community and which gather together, primarily on a Sunday. We should also keep in mind that there is an important connection between these two kinds of church. As Evelyn Underhill, the $20^{\text {th }}$ century Anglo-Catholic theologian stresses, it is important to recognise that in some sense, all worship is a part of the worship of the whole Church. She writes,

It is plain that the living experience of this whole Church, visible and invisible, past and present, stretched out in history and yet poised on God, must set the scene for Christian worship; not the poor little scrap of which any one soul, or any sectional group, is capable. Thus there must be a traditional worshipping act of the Church, a great liturgical life, of which the sectional worship of its various groups and branches will form a part, and to which the many-levelled action of its isolated members with all their varying moods and insights contributes; an act which includes and harmonizes all apparent differences. (1936, 85).

These remarks help us to situate the context of the Church's worship. However, whilst this context is important, in giving an account of the group actions involved in worship, my primary focus will be on a gathered church and not the whole Church. Yet, even in a local, gathered church

\footnotetext{
${ }^{9}$ With thanks to an anonymous referee for suggesting this clarification.
} 
context there is an important role for group action. We can see this clearly in Stanley Hauerwas's writing on ecclesiology. Hauewas writes that,

Gathering indicates that Christians are called from the world, from their homes, from their families, to be constituted into a community capable of praising God...The church is constituted as a new people who have been gathered from the nations to remind the world that we are in fact one people. Gathering, therefore, is an eschatological act as it is the foretaste of the unity of the communion of the saints. $(1995,157) .^{10}$

Thus, even in a small scale gathered church community, Hauerwas thinks it important to emphasize the community's worship of God and not merely the individual's. Indeed, as we can see, he maintains that there is some kind of resemblance between a gathered church and the whole Church. Yet, even at a small, gathered level, this question is still philosophically challenging-it is far from clear how a gathered group of individuals could be regarded as an agent of worship.

With these theological issues outlined, we can now think more carefully about what the best model for understanding a gathered church's actions in worship is, and then to see how such an account handles non-paradigm participants.

\section{Liturgical action}

To provide a model of group liturgical action, it will first be important to think more generally about what it is to engage in liturgical action. To do this, I consider two recent accounts of liturgical action which will help inform the proceeding enquiry.

In recent work by Terence Cuneo (2016) and Nicholas Wolterstorff $(2015,2018)$, both seek to give a philosophical definition of what it is to act liturgically. ${ }^{11}$ Cuneo argues that the

\footnotetext{
${ }^{10}$ This emphasis on the church's gathering from a variety of spheres of society is discussed in detail by Smith (2009, 159-166)

${ }^{11}$ Another philosophical account of liturgical action can be found in James K.A. Smith's (2009) work on liturgy. Smith maintains that liturgy is not something which is contained only to church services, but, rather, it is something which pervades all aspects of our life; human beings are worshipping creatures, or, 'bomo liturgicus', to use his terminology (2009, 37-42). Whilst we cannot cease from worshipping, Smith holds, we can become more aware of what and how we worship and this can illuminate our understanding of the actions involved in corporate worship. As Smith notes, 'it is important also to keep in mind that worship is best understood on the order of
} 
seemingly random collection of bodily actions from his own Eastern Orthodox tradition are a collection of scripted activities which are 'constituents of an identifiable pattern' $(2016,155)$, that of 'blessing, petitioning, and offering thanks to God' $(2016,156)$. It is not the case, according to Cuneo, that these bodily actions merely accompany the linguistic acts of petitioning or blessing, but, rather, he argues, in the context of liturgy, these bodily actions 'count as cases of engaging God by blessing, petitioning and thanking God' $(2016,156)$. Wolterstorff provides a similar account of liturgical action, using the analogy of a piece of music to explain the relationship between the script, our bodily actions and the non-bodily actions involved in worship. A musician follows a score to guide her to perform a certain sequence of sounds, in such a way that 'the musical work is the sound sequence type that is instantiated when the correctness-rules that the composer has instantiated are faithfully followed' (2015, 6). Similarly, a liturgical script 'specifies a set of rules for a correct liturgical enactment' $(2015,7)$, which, in turn, allows for the performance of certain acts of worship.

To see how this account works, let us consider a specific example from Wolterstorff. In reading and listening to lines of liturgy and passages of Scripture, Wolterstorff thinks, an individual can engage in a kind of mutual address with God. For instance, in using the second personal pronoun in the liturgical script (e.g. 'Eternal God, heavenly Father, you have graciously accepted us as living members of your Son our Savior Jesus Christ' (Book of Common Prayer, 365, quoted in Wolterstorff, 2015, 56)), a person can 'strongly address' God $(2015,58)$. That is, they can address God with the 'expectation or hope that one's addressee will realize that they are being addressed' $(2015,58)$. Furthermore, in listening to lines of the liturgy from the priest or the other congregants, Wolterstorff maintains that an individual might listen to God. The assumption in much of the Episcopal liturgy, he notes, is that 'people have been listening not just to the speaker but to what God said or says' $(2015,64)$. Thus, on Wolterstorff's account, these mundane acts of listening and speaking, in the context of worship, can count as acts of engaging in mutual address with God.

action not refection; worship is something that we do' $(2009,166)$. For Smith, the actions involved in corporate church liturgies play an important role in shaping and moulding the worship of both the community and the individual. Bruce Ellis Benson's (2013) discussion of liturgy follows a similar line to Smith's in thinking of liturgy in a broader, more holistic sense, rather than focusing only on corporate acts of worship. 


\section{Group liturgical action}

Whilst the above accounts of acting liturgically are helpful, we are yet to see how acting liturgically might be considered a group action. ${ }^{12}$ In many respects, this is an issue which is not unique to the actions of a church; in every day speech, we ascribe actions to groups-we speak of the government's investment in public services, a football team's excellent passing movement, and a rock band's engaging performance. If, as we have been assuming, a gathered church is a group constituted by many individuals, then acting as a group in worship may be no different to a football team's tactical movement or a rock band's synchronicity on stage.

Helpfully, there is a vast philosophical literature devoted to thinking about how individuals can act together as groups. By paying attention this literature, we can gain a better grasp on the communal nature of liturgical action.

First, there are many cases of group action which are instances of what Deborah Tollefsen describes as 'shared agency' $(2015,3)$. As Tollefsen defines it, shared-agency refers to 'the ability of individuals to engage in joint actions such as moving a table together, painting a house together, or playing a game of chess' $(2015,3)$. In explaining cases of shared-agency, philosophers usually provide some kind of account which refers to the meshing or joining of the individual intentions involved in the group action. I will consider one such account in the next section.

${ }^{12}$ We see some attempt in Wolterstorff's work to consider this question. He writes that,

The church enacts the liturgy not to satisfy the needs and desires of individual congregants but to worship God....It's not the individual members who do these things simultaneously; it's the assembled body that does these things. $(2015,11)$

Whilst there is no attempt to give such an account in The God We Worship, there is a way of extending what Wolterstorff writes to accommodate corporate action by looking at Cuneo's work on corporate acts of worship. Indeed, in his forthcoming book, Acting Liturgically, Wolterstorff will address this issue of collective worship by drawing on much of the same literature that I will consider in the next section of this paper. Smith devotes more time to the question of corporate worship than Wolterstorff. For instance, he writes that, 'worship is not a private affair; we have gathered as a people, as a congregation, and just as we are dependent on our redeeming Creator, so too are we dependent on one another' $(2009,169)$. 
However, we might also describe a kind of group action which goes beyond individuals acting together in individual cases. Tollefsen notes that, ' $[\mathrm{w}]$ hen two people take a walk together they are engaged in a form of shared-agency, but in doing so they do not form a unified agent to which we attribute beliefs, goals, and intentions' $(2015,5)$. For example, the government's investment in public services might involve some kind of shared-agency, but there is arguably more to this action than the synchronisation of multiple individual intentions. Following Tollefsen, we can describe the government's actions as an example of group-agency. That is, we can provide an analysis which seeks to explain how the group as a whole can perform some action as the result of a decision-making process. In discussing the agency of a particular group, as Tollefsen clarifies, philosophers have been interested predominantly in corporate groups, groups that 'have a structure and a decision-making process' (2015, 3). Furthermore, in general, corporate groups maintain their identity, despite changes in membership. Thus, for instance, when Teresa May took over as Prime Minister of the United Kingdom after David Cameron's resignation, it still made sense to refer to the government's investment in public services, despite most of the ministers in the government being replaced. The government as a group-agent survived this change in membership.

Building on the account of liturgical action outlined previously, along with the distinction between group-agency and shared-agency, we are now in a position to outline two models for thinking about group liturgical action.

\section{Shared-agency and liturgical action}

First, let us consider how an account of shared-agency might help to explain the actions involved in corporate worship. In his analysis of liturgical singing, Cuneo attempts to give a model of liturgical action which builds on the philosophical literature on shared-agency. Whilst the particular focus of Cuneo's chapter is on sung liturgy, this is primarily a feature of the context of his discussion, namely, the Eastern Orthodox liturgy, which is almost entirely sung $(2016,126)$. Thus, as I will suggest, this analysis can be extended much further than is implied by Cuneo's discussion. According to Cuneo, singing as a part of a group requires a kind of responsiveness to the other singers present which is not required when singing alone $(2016,135)$. To engage in the group act of singing, we must pay attention to what the other individuals are doing, and one's own actions do not stand on their own, but, rather, they are part of a larger act which is performed by the congregation.

To show how we might make sense of these observations, Cuneo maintains that we can appeal to the philosophical literature on shared-agency. More specifically, Cuneo appeals to 
Searle $(1990,2010)$, who maintains that we can make a distinction between individual intention and group intention by considering two different examples of group action:

Imagine that a group of people are sitting on the grass in various places in a park. Imagine that it suddenly starts to rain and they all get up and run to a common, centrally located, shelter. Each person has the intention expressed by the sentence "I am running to the shelter." But for each person, we may suppose that his or her intention is entirely independent of the intentions and behavior of others. In this case, there is no collective behavior; there is just a sequence of individual acts that happen to converge on a common goal. Now imagine a case where a group of people in a park converge on a common point as a piece of collective behavior. Imagine that they are part of an outdoor ballet where the choreography calls for the entire corps de ballet to converge on a common point. We can even imagine that the external bodily movements are indistinguishable in the two cases; the people running for shelter make the same types of bodily movements as the ballet dancers. Externally observed the two cases are indistinguishable, but they are clearly different internally. (1990, 403-404)

Searle maintains that even if these cases are behaviourally indistinguishable, the first is a case in which all the agents act in the same way, each with a similar intention, and the second requires the individuals to have what he calls 'we-intentions'. By 'we-intention', Searle means that the individuals have a collective intention which is not reducible to the intentions of each individual agent. In other words, in the first case, the group all happen to do the same action at the same time, and, in the second case, the group cooperate to perform an action together.

Although most philosophers would agree that there is a distinction to be made between these two cases, there is some disagreement about how best to analyse this distinction. ${ }^{13}$ Because of this, there are many possible ways of analysing the collective intentions involved in worship. Here, I follow Cuneo in using Searle's analysis. For Searle, collective intention is not reducible to individual intention. He distinguishes, for instance, between a case in which a group of economics students all graduate with the intention to put Adam Smith's theories into practice

\footnotetext{
${ }^{13}$ The literature on collective intention is vast and a survey of the positions one could hold would be much longer than the intended length of this paper. For the key positions in this debate, see Tuomela 2013, Bratman 1999, Miller 2001, Velleman 1989, and Searle 1990, 2010. For an excellent summary of the above literature, see Tollefsen, 2015, 27-50.
} 
with an awareness of the intentions of others, and a case in which the graduates make a solemn pact to put Adam Smith's economics into practice after their graduation (2010, 47-48). The difference between these two cases, according to Searle, comes down to the role of cooperation, which, he thinks, is crucial in giving an account of collective intention. He writes, 'Cooperation implies the existence of common knowledge or common belief, but the common knowledge or belief, together with individual intentions to achieve a common goal is not by itself sufficient for cooperation' (2010, 49; emphasis in the original). Thus, on Searle's account, when cooperation is present in this way, the structure of our intentions is different. To take an example which Searle uses, that of the piano/violin duet $(2010,52)$, it is not that I-intend that I play the piano whilst believing that you play the violin. But, rather, as he describes it,

We are performing a duet where I play the piano part and you play the violin part. Here our playing does not cause the duet to be performed. My playing and your playing simply constitute the performance of the duet. So from my point of view, I have a collective intention-in-action that we play the duet by way of me playing the piano, in a context where $I$ take it for granted that you are playing the violin. (2010, 52; emphasis in the original)

In Searle's example, my intention is a collective intention rather than an individual intention. Searle thinks that it is not the case that I merely intend to play the piano and I believe that you will play the violin, as he thinks some accounts of collective intention describe. But, rather, according to Searle, the content of my intention is different when I act cooperatively than when I act individually — we intend to act collectively. Whilst Searle thinks that I must have certain beliefs about what the other will do, these beliefs are not what make my intention collective, but, rather, there is something irreducible about the nature of my intention when I act cooperatively. Now, with Searle's position outlined, let us consider Cuneo's application of this analysis to explain the nature of liturgical singing. Cuneo writes,

Group singing clearly seems to satisfy the criteria for collective action specified above: it requires the requisite "we intentions," that these intentions fit together in the right ways, and an awareness of one another's intentions... to engage in group singing also requires that I adjust my singing to yours and that you adjust your singing to mine in "real time," often in ways that are not dictated by the score that we are following. $(2016,138)$. 
We can see how Searle's analysis is helpful in explaining the nature of the collective act of singing. Just like the piano and violin players who cooperate to perform the duet, the congregation need to employ some kind of cooperation or responsiveness to collectively sing the lines of the liturgy. Thus, on Cuneo's analysis, it is not the case that congregants intend individually to sing, but, rather, they we-intend that the liturgical script is sung by means of their individual performances.

Whilst Cuneo's analysis focuses on the specific example of liturgical singing, it appears promising as an account of liturgical action more generally. Indeed, as we have seen, if we are to regard a church as the proper agent of worship and not merely the individual congregants, then an account of collective intention appears to provide an analysis which allows us to make this the case. To return to Wolterstorff's example of mutually addressing God, let us consider how Searle's analysis might be adapted in the case of our addressing God as a congregation. In the congregational action of addressing God, there are many individual actions which constitute the action, namely, each individual's reading of the liturgical script. Thus, just as Searle gives the analysis of performing a duet constituted of two parts, we can give a similar analysis of the intention involved in addressing God. That is, although I do form the intention to read my part of the liturgical script, just as the duet playing pianist forms the intention to perform the piano part, this singular intention is a constituent part of my intention that we address God. If addressing God in corporate worship is something that we do, then it must be part of our intentions that we perform the action, and not just that I perform the action. Just as the duet players each intend their constituent parts whilst also intending to perform the piece as a collective, the individual intends to play their part in worship whilst intending to worship God as a congregation.

This extension of Searle's analysis of collective intention to liturgical worship gives us a clear model of how individual actions can be related to the actions of a gathered church. Indeed, in cooperating with the other members of a congregation, our intentions can somehow combine to form a collective intention, and thus a collective action. However, whilst the literate on shared-agency is useful in explaining how actions such as reading and singing might be coordinated, it cannot provide a complete account of the actions of a worshipping church. ${ }^{14}$

\footnotetext{
${ }^{14}$ It should be noted that this is no criticism of Cuneo's or Wolterstorff's accounts of liturgical action; neither are attempting to give a complete account of the Church's corporate acts of worship, but, rather, they seek to provide some analysis of some of the actions involved in worship.
} 


\section{Shared-agency and inclusivity}

In this section, I consider how well a shared-agency model of group liturgical action can handle non-paradigm participants in the church's worship. Whilst clearly there are examples of instances of shared-agency in corporate worship in, say, the singing of the liturgical script or the repeating of the Lord's prayer in unison, I will argue that there are limitations to the shared-agency model which mean that the group-agency model has more explanatory scope.

Problematically for the shared-agency model, in basing an account of group liturgical action on collective intentions, we must assume that all members of a congregation can form 'we-intentions'. Yet, there are clearly members of most, if not all, congregations who are simply unable to engage in this kind of complex coordinated group action. Young children, some elderly individuals and some neuro-atypical individuals would surely find it difficult, if not impossible, to participate in shared-agency in way described above. ${ }^{15}$ Such an account requires a level of competency and social attentiveness which appears to exclude many individuals from contributing to the actions of a church's worship.

To see this point more forcefully, I will focus on how individuals with ASD might participate in the church's worship, conceived in these terms. As recent psychological literature on ASD has shown, such individuals have difficulty, or cannot, form 'we-intentions'. As Tomasello, et al. note in their discussion of the neurological basis for shared intention amongst humans,

[c] hildren with autism show very little coordinated joint engagement, and initiate very few bids for joint attention with others by declaratively pointing to or showing objects...With regard to collaborative engagement, children with autism engage in relatively little cooperative play with peers and in general collaborate with others very little...the vast majority of children with autism do not participate in the cultural and symbolic activities around them in anything like the normal way. $(2005,686)$.

In agreement with these findings by Tomasello, et al.., Colombi, et al. argue that, 'that an impairment in imitation and joint attention alters developmental trajectories involving cooperative development and prevents children with autism from fully participating in

\footnotetext{
${ }^{15}$ Yet, as N.T. Wright argues, 'God has ways of making himself known intimately to children from their earliest days. Perhaps one of the-dare I say—sacramental ways by which God does that is precisely by the loving welcome of the Christian community' (2008).
} 
cooperative tasks' (2009, 158-159). Whilst the precise neurological mechanisms which underpin collective intentionality are up for debate, what seems uncontroversial from the psychological literature is that autistic children struggle to engage in cooperative activities in the same way as neuro-typical individuals. Furthermore, it also seems clear that this developmental difference in some autistic individuals can have a significant impact on their ability to engage in cooperative tasks later in life. There are at least some individuals who would simply be unable to participate in worship as a collective action in the way described previously, or, at the very least, they would find such engagement profoundly difficult. For instance, consider Ann Memmott's description of what it is like for a person with autism trying to follow a Eucharistic service. She writes,

Just when my ability to cope is at its lowest ebb, I have to try to understand what I do for Communion. People know when to stand up, when to move forwards (apparently they know to do this just by looking at where someone is standing and noticing the slightest nod of the head. I don't notice this.). I have to work out which bit of kneeling-cushion to aim for, or where to stand, how long to wait before going up there. What to do with my hands when I get the bread and wine and what to say and when. The rest of the people know when to stand up again, when to go back, when to say something like AMEN when you're up there. $(2015,9)$.

Similarly, Barabra Newman describes the challenges individuals with ASD face in participating in corporate worship. She notes, for instance, that,

many churches assume that people have attended a worship service before and that they can quickly adapt their behavior to fit in with the rest of the people in a specific setting. People with ASD — and many visitors too-find this assumption intimidating, and it keeps them from attending church and participating in the life of the church. $(2011,73)$.

Newman notes that knowing when to say 'amen', what to do during offerings, how to engage in communion, how loudly and when to sing, can all be challenging to individuals with ASD if insufficiently explained $(2011,73) .^{16}$

\footnotetext{
${ }^{16}$ As Newman notes, ASD indicates a 'range of behaviors and needs' (2011, 23); she highlights the need for churches to understand the particular needs of individuals, rather than applying blanket rules across the board $(2011,23)$.
} 
All the above appears to be problematic for the shared-agency model of group liturgical action. It seems strange to suggest that autistic individuals are excluded from the actions of a church since they lack the capabilities to cooperate in the manner required for collective intention. If Paul's words in 1 Corinthians are to be taken seriously, then surely individuals with ASD are precisely those who he urges the Church to include. The lack of inclusivity in the shared-agency model points to a crucial difference between a church community and other forms of social group - the actions of a church in worship cannot be limited to only those who are able to engage in high-level coordinated action.

However, it may be possible to rescue a shared-agency model by providing ways of accommodating neuro-atypical individuals in worship. There are small accommodations that can be made in Church worship to include such individuals; in her guide for helping churches cater for individuals on the autistic spectrum, Memmott describes how collective worship can be structured in a manner which caters for autistic individuals. She imagines a Church service which is set up for such an individual:

The Vicar had already met with me to show me the church, and it has a good website 'blog' with pictures and service updates on it so that I know what will happen. ... The people in the congregation are really friendly and they know to introduce themselves each time if I don't greet them by name, so I don't have to try to guess who they are. There's someone who is a quiet friend to me in the congregation, who can explain changes or explain anything I don't know or don't understand from the service. In The Peace, people know that I'm not being rude if I miss eye contact or want to stop shaking hands for a while. No-one is offended. The service sheet has 'stand up' and 'sit down' written in the right places so it's so easy to follow. $(2015,9-10)$.

We might also stress that there can be different levels of participation involved in worship. Whilst not all people can be involved in the act of collective singing or reading the liturgy in the right way, this does not mean they cannot be involved at all. ${ }^{17}$

However, whilst these suggestions of accommodation are important, it is possible to accommodate an individual without truly including them in worship as an equal contributor. Metaphorically speaking, if we think of the worship of a church as the performance of a piece of orchestral music, it might be possible to accommodate individuals in such a way that they can

${ }^{17}$ Thanks to anonymous referee for this suggestion. 
feel comfortable appreciating the music of the orchestra, but proper inclusivity means that all of the players can play their own instrument in the orchestra, and the same is true for the performance of worship. As Benjamin Conner argues, 'accommodating people with developmental disabilities so they can be present in a nondisruptive way is not enough; we must challenge church structures. We must be realistic about the structural changes that must attend becoming an inclusive church' (2012, 92).

It is important to avoid the implication that to contribute to a church's worship, those who have difficulties in forming we-intentions should fit around those who are typical. In considering the role of neuro-atypical individuals in the Church, we must speak not only of accommodating, then, but we must also consider what such individuals can contribute. As Kevin Timpe explains, drawing from the work of disability consultant Cara Milne, 'integration is not the same as inclusion' $(2017,20.04)$. Whereas integration includes the provision of legal rights and protection for individuals with disabilities, inclusion goes further, and requires 'full opportunity for participation and value in one's social environments' (2017, 20.15). An account of a church's acting in worship should be one that not only integrates those with neurological and physical differences into the work of a church, but also includes them as a constitutive part of a church's actions in worship. Yet, it is difficult to see how a shared-agency account can provide such a model of group action. ${ }^{18}$

\section{Group-agency}

We can now consider how an account of group-agency might provide a more inclusive model of group liturgical action. ${ }^{19}$

\footnotetext{
${ }^{18}$ To be clear: to point out that a shared-agency model has difficulties providing and inclusive account of worship is not to claim that the account of shared-agency in liturgical singing offered by Cuneo is not fit for purpose. As we have already seen, shared-agency and group-agency are attempting to explain different phenomenon. Whilst shared-agency is well suited to explain the coordinated action of singing the liturgy, it cannot explain all of the kinds of involvement in a church's worship. This limitation of the shared-agency model, in explaining only the participation of the neruo-typical in certain acts of liturgy, points to the need for a broader, pluralistic model of Church agency.

${ }^{19}$ The literature on group-agency is vast. Tollefsen (2015) gives a detailed overview of the key positions in Chapter 3 of Groups as Agents. Here, I focus only on List and Pettit's account.
} 
As Tollefsen notes, 'in everyday contexts we often talk as if groups were agents with attitudes such as belief and intention' $(2015,1)$. Moreover, such actions do not seem to be analyzable only in terms of shared-agency. Indeed, there seem to be some cases in which we might ordinarily think of groups as the originators of certain actions in which there is no sharedagency. A government's acting in response to a global crisis might involve the coordinated actions of cabinet of ministers, but it might sometimes involve only the actions of one individual who is authorized to act on behalf of the group. Shared-agency accounts cannot explain all instances of group action.

Rather than analyzing specific actions, and considering what role individuals play in these actions, accounts of group-agency tend to focus first on the nature of agency, and then to think about how a group of individuals might fulfil certain criteria for acting. For instance, Peter French (1995) argues that agents must display the capacities for intentionality (i.e. they must do something for a reason or purpose), rationality (i.e. they must be responsive to arguments that concern these reasons) and, they must be able to respond to criticism (i.e. they must be capable of adjusting their actions accordingly) (1994, 10-12). French maintains that many corporate groups meet these criteria, and so should be considered agents. Similarly, List and Pettit give the following conditions for agency:

an "agent", on our account, is a system which these features: it has representational states, motivational states, and a capacity to act on their basis. When processed appropriately, the representational states co-vary with certain variations in the environment: for example, with the changing positions of cylinders. And the motivational states leave the agent at rest on trigger action, depending on whether the motivating specifications are realized or unrealized in the represented environment. $(2011,20)$

On their account, to be considered an agent, something must have (1) representational states, (2) motivational states, and (3) a capacity to act on these states. Note that these conditions for agency are very minimal. ${ }^{20}$ Thus, if a robot can process information about its surroundings and act accordingly, it should be considered an agent. ${ }^{21}$ It is important to note here that an agent is

\footnotetext{
${ }^{20}$ No account of group agency is without its problems. Whilst I focus primarily on List and Pettit's account here, this is one way amongst many of giving an account of group-agency.

${ }^{21}$ In expanding this discussion, List and Pettit write that,
} 
not the same as a person on this analysis. ${ }^{22}$ To ascribe agency to something is only to claim that it is somehow the originator of a particular action, or set of actions. As Tollefsen notes, this need not commit one to thinking that all agents are phenomenally conscious $(2015,53)$. Indeed, none of the accounts described above think that groups are capable of phenomenal consciousness, but rather, they describe mental states (such as intentions) in broadly functionalist terms which do not require that propositional attitudes can only be held by phenomenally conscious agents. The shortcoming of such an approach, Tollefsen suggests, is that if you are a person that thinks that propositional attitudes are states only of phenomenally conscious beings, then group mental states are going to be a particularly difficult thing for you to swallow' $(2015,53)$.

Assuming some version of the above conditions for agency is plausible, it seems possible that just as an individual or robot could meet these conditions by having the relevant motivational states and representational states, a group of individuals, organised in the correct way, could also meet these criteria. In providing an account of group agency, it is important to see that not any collective of individual would meet the above criteria. As Tollefsen notes, 'corporate groups' unlike 'aggregative groups' have a 'structure and a decision-making process' $(2015,3)$ which makes it possible for them to act as agents. Similarly, List and Pettit note, corporate groups have 'an identity that can survive changes of membership' (2011, 31), such as 'a nation, a university, or a purposive organisation' $(2011,31)$.

To see how such groups could fulfil criteria for agency, I will consider two kinds of groups which List and Pettit claim can be structured in such a way that agency is possible. The first possibility concerns groups in which no shared-agency is involved, and the second concerns

Representational and motivational states, which we also call "intentional states", are configurations in an agent's physical make-up that play a particular role or function in engaging with other such states and in producing action. A state is "representational" if it plays the role of depicting the world, and "motivational" if it plays the role of motivating action. ... We make no assumptions about the precise physical nature of intentional states. They may be of a wide variety of kinds. ... We only require that they be configurations of the agent-or perhaps configurations of the agent in context-that play the appropriate functional role. $(2011,21)$.

${ }^{22}$ Whilst on the account of personhood they eventually give $(2011,170-185)$, all persons are agents, not all agents are persons. 
groups which act (at least partly) by means of shared-agency. First, let us consider an account of group-agency which does not involve shared-agency.

First, It is possible, List and Pettit argue, by 'a process of natural or cultural evolution', that 'members are selected for possessing traits that lead them to act as required for group agency' $(2011,32)$. Although, as they admit, there are no obvious examples of human beings combining in this way, there are many examples from other species. They note, for example, that certain studies of bee hives show that 'bees can combine, on the basis of simple signals, so as to perform as a group agent' $(2011,33) .{ }^{23}$ For instance, in a study by Thomas D. Seeley (2001) on the behaviour of bee colonies, Seeley observes that groups of bees 'often possess impressive powers of decision making, especially with respect to simultaneous-option decisions' (2011, 249). Yet, remarkably, no one member of the colony can have this level of cognitive processing by itself. Thus, although the bees do not collectively intend to make decisions, the structure of the colony as a whole means that conditions for agency can be met by the actions of the group. Or, to give another example, consider a terrorist cell at the ground level. In such a group, there are 'one or several organizational designers co-opting others into a structure underpinning groupagency, without making them aware of their agency at the group level and without seeking their intentional acquiescence in the arrangement' (List and Pettit 2011, 33).

Secondly, it is possible for a group to exhibit group level agency by means of various instances of shared agency. In such cases, a group of individuals 'intend that they together act so as to form and enact a single system of belief and desire, at least within a clearly defined scope; they each intend to do their own part in a salient plan for ensuring group-agency within that scope, believing that others will do their part too' $(2011,34)$. However, the kind of cooperation that is necessary for this kind of group-agency, according to List and Pettit, need not require that each individual is an 'equal and willing partner' in the composition and actions of the group (2011, 34). Whilst, on such a model, some shared-agency is required, not all members of the group are required to have an equal stake. Indeed, as they go on to note, there are two ways in which an individual might be related to such a group. They might take an authorizing role, or an active role. If the individual takes an active role, then they act with 'full awareness for the pursuit of the group's ends' $(2011,35)$. That is, they act wholly or partly on behalf of a group when they act. However, the individual might also take an authorizing role, that is, they might simply accept the group as an agent and allow the group to speak on behalf of its members, such as in the case

${ }^{23}$ To consider this example in more detail, see Seeley 2001 and List, Elsholtz, and Seeley, 2009. 
of being a member of a trade union $(2011,35)$. In such a case, someone is the member of a group, yet their own actions and intentions play no role in the actions of that group.

They key feature of the above analysis which is useful in application to acts of worship is that even in cases of group-agency which do involve shared-agency, not all the agents need to play the same role in performing the group action. Indeed, the role that one plays in relation to the group depends on (a) the structure of that particular group in making decisions and forming judgments and (b) one's relation to the structure of the particular group. For example, in the case of a tyrannous regime, what it is for a government to have group-agency is true only in virtue of the actions of the tyrant, so long as the individual members authorize the tyrant's actions in some way. But, it is still true, at least in some sense, that the group acts when the tyrant acts. As List and Pettit argue,

In a jointly intentional group agent, the two types of members are typically present and often overlap. In a participatory group like a voluntary association, members have the same status within the group agent; they equally authorize the group agent and take roughly equal parts in acting on its behalf. In a hierarchical organization, such as a commercial corporation or a church, there may be differences in the members' roles, for example through holding different offices or through belonging to subgroups with different tasks. $(2011,36)$.

An account of group-agency seeks to provide a very different kind of explanation of group action than an account of shared-agency. As Tollefsen highlights, "the connection between group-agency and shared-agency is not always clear in the literature' $(2015,5)$, but it seems that two are importantly related. As we have seen, shared-agency is sometimes involved in groupagency, but not always. An account of group-agency attempts to attribute an action not to a number of coordinated individuals, but, rather, to a group, an entity with its own decisionmaking processes. In some cases, the conditions for agency are met by the democratic votes of the members of the group in which they jointly intend an action, in other cases, these conditions are met by a hierarchical structure in which a small senior group of individuals jointly intend on behalf of a much larger group of individuals. In other cases, the individual agents display no (or little) shared-agency, yet, because the group of individuals is structured in a particular way, it is possible for the group to form goal orientated representational states which go beyond the mental states of the group members. 
In the next section, I consider whether an account of group-agency might provide a broader, pluralistic model of the church's acting in worship than we have so far considered.

\section{Group-agency and liturgical action}

To give an account of group-agency in liturgical worship, we need to say something about a church's ontology. And whilst there is not space here to give a fully worked out ecclesiology, it is possible to make some general observations that can help us to consider how an account of group-agency might help to explain group action in worship.

First, it is important to see that there are also some features of Christian worship which have striking similarities to other social structures, which can help us to see the ontology of certain kinds of congregational groups. However, such an analysis will not apply equally to all congregational structures. The ontological structures of free Church group agents will differ from those of Anglican group agents, for instance. One particular example of such differences can be found in thinking about how different traditions account for Church membership. As we have seen, in order to give an account of group-agency, we need an account of group structure and an account of group membership.

Now, in many free Church contexts, to be a member of a specific Church is to be baptized, to ascribe to a certain doctrinal statement, and to adhere to certain behavioral standards. In contrast to this, in Anglican Churches, membership is often regarded as synonymous simply with baptism. In the Anglican Church, baptism is often available to infants and those with severe neurological impairments, given that parents and godparents can make promises on their behalf. Thus, when a church congregation acts as a group in worship in the Anglican context, simply in virtue of their baptism, a young infant could be considered a part of that church's worship. Just as a worker should be considered a part of the trade union's industrial action, in virtue of her being a member of the trade union, any baptized individual should be considered a part of a church's actions in worship.

As we saw in List and Pettit's work, there are at least two ways in which an individual who is a member of a group might contribute to a group action. First, let us consider a kind of authorizing action. Underhill, writing on group on action in worship, notes that in some forms of worship, the priest or a group of elders are seen as acting on behalf of the whole congregation in prayer. In such a case, she notes, 'action and speech are delegated to a person or group; the congregation uniting itself by intention to that which is done. Thus, a focus is provided, a certain unity of direction is ensured; and the liturgical action covers and unites the devotion of simple and learned' $(1936,96)$. We might think, then, that in some contexts, the priest holds a similar 
role to the CEO of an organization in the actions of the Church in worship-there are actions which only he or she performs, but which are counted as actions of the group. As Underhill describes, in some traditions, the Daily Office is chanted by a choir or group of monks on behalf of the whole Church $(1936,96)$. Such representative action would surely include some form of shared-agency from those participating in the spoken liturgy, yet, by also giving an account of group-agency, we can see how all of those who are considered members of a church can in some way be a part of these liturgical acts. In belonging to a church community through baptism, or by some other form of membership, one takes an authorizing role in recognizing those who act in providing representative group action in worship. Note that unlike most cases of authorization, those churches which allow for infant baptism, or baptism of those with severe neurological impairment, involve a complex kind of authorized action. In the case of infant baptism, just as the parent makes promises on behalf of the child which relate to her faith in Christ, the parent can also be seen as making a kind of representative authorization action-that is, the parent authorizes the relevant authorities in a church structure to speak on behalf of the child in worship.

Secondly, let us consider how individuals might play an active role. As List and Petit acknowledge, there are a variety of ways of playing an active role in a group's acting:

Ordinary believers are usually not as active in a church as priests and bishops but they still authorize the church equally, taking it to speak for the group in religious matters. Ordinary workers do not authorize a commercial company in the manner of shareholders and directors - it is these agents who provide the money and the votes that keep the firm on track-but they play a similar if not greater part in acting on behalf of the group. $(2011,36)$.

Whilst the individual's active role in a group will no doubt be different to that of a priest or elder, they can still contribute to the actions of the group. Indeed, the examples they give of playing an active role in a group include, 'the members of a church in participating in religious ceremonies or in proselytizing among non-believers' $(2011,35)$. The organizational structure of a church will depend, in part, on one's tradition, but it seems clear that a member of a church, by participating in the reading of liturgical scripts and singing hymns can act on behalf of the group in a manner analogous to a member of a trade union acting on behalf of a group by standing on a picket line. 
Note that these kinds of actions might be performed through acts of shared-agency, such as the singing of the liturgical script, but we might also include many other actions as instances of playing an active role in a group. Just as organizations need both sub-committees and expert individuals to contribute to the actions of the group, the individual actions of neuro-atypical individuals could rightly be considered as playing an active role in the actions of the group. We will consider this possibility in more detail shortly. In order to act in this way, List and Pettit note, individuals 'must be licensed by the group as being fit to do this, for example, by belonging to a suitable category or meeting criterion such as having paid a fee or being accepted by other members' $(2010,35)$. I assume, in the context of Church worship, what constitutes this kind of licensing is the baptism of the individual, in which the Church recognizes that individual as belonging to God and belonging to the body of Christ, the Church.

We must also consider the issue of group rationality in the context of worship. As List and Pettit note, 'to count as an agent, a group must exhibit at least a modicum of rationality. And so its members must find a form of organization that ensures, as far as possible, that the group satisfies attitude-to-fact, attitude-to-action, and attitude-to-attitude standards of rationality' (2010, 360). It would appear that most churches have the organizational structure to make such a decision-making process possible, whether that be through a Parish Council, a board of elders, or annual general meetings. Whilst, in worship, we might think very broadly about who or what contributes to the actions of the group, it is still important for a church as a group to have some kind of structure to reflect on the practice of its members. And thus, whilst a person's baptism might ordinarily be sufficient for them to be considered playing an active role in a church's group worship, there might be cases in which the decision-making processes of the group seek to exclude that individual from playing such a role.

Finally, before considering the issue of inclusivity and group-agency, it will be helpful to refer back to the broader theological picture of the Church to see in what ways church groupagency differs from other examples of group-agency. As discussed in the opening section, the Church as a whole is constituted by many individuals, and many assembled congregations. Furthermore, as we saw emphasised in Underhill's work, the unity of the whole Church is something which comes about by the work of God in a way which is somehow mysterious to us. She writes that each individual in the Church 'forms part of a social and spiritual complex with a new relation to God; an organism which is quickened and united by that Spirit of supernatural charity which sanctifies the human race from above, and is required to incarnate something of this supernatural charity in the visible world' $(1936,83)$. 
One way of claiming that the whole Church is engaged in worship through the seemingly disparate actions of Church congregations and individuals is to appeal to claim that the whole Church has a kind of agency made possible by the work of the Spirit. This seems to fit well with the kind of group List and Pettit describe which is structured as an agent but with little or no awareness from the members that constitute such a group. In the case of a bee colony or a ground level terrorist cell, for instance, there is evidence of agency at the group level, even if not at the member level. Such groups can, List and Petit maintain, act on representational and motivational states due to the organisational structure of the group, made possible by the biological impulses of the bees, or the commands of the terrorist leaders. Now, such a model seems helpful for accounting for the agency of the Church as a whole. If, as Underhill claims, the Holy Spirit works to unite the members of the Church into forming a whole organism, capable of responding to God in worship, then the work of the Spirit might be seen to operate much like the biological impulses of the individual bees, or the instructions of higher level terrorist commanders. On such a model of the Church's agency as a whole, we can note that even if there is no sense of corporate action involved in gathered worship, or indeed, even if worship is done in solitude, the mundane acts of singing, speaking, standing, sitting, and so on, can be united together by the work of the Holy Spirit to somehow contribute to the Church as a single group agent. As Underhill notes, 'even [the worshipper's] most lonely contemplations are not merely private matter; but always to be regarded in their relation to the purpose and action of God Who incites them, and to the total life of the Church' $(1936,83)$. It is important to see that all acts of worship, whether by some kind of cooperation or shared-agency, or whether they be the acts of those who feel excluded from the worship of the Church, can be seen as part of a wider act of worship, made possible by the work of the Holy Spirit. Furthermore, the same might be said about the gathered church as well as the whole Church; regardless of the human structures which enable unity in worship, it is important to recognize that there is a certain kind of divine action involved in corporate worship which distinguishes it from other social structures. The Holy Spirit unites the actions of a gathered church in worship to provide a kind of supernatural agency, even at a congregational level.

Fully expanding the role of the Holy Spirit in the worship of the Church is beyond the scope of the present discussion, yet, it is important to say something about what practical difference this might make to the worship of gathered church communities. As Bruce Ellis Benson (2013) describes, the Holy Spirit can play a practical role in guiding and leading a church's worship. Whilst this might often be thought of as a characteristic only of Pentecostal or 
Charismatic churches, this need not be the case. As Benson writes, reflecting on his visit to a formal liturgical church, 'Saint Gregory's',

In general, members of so-called nonliturgical churches value spontaneity, a feeling of being fresh and authentic, since those praying, for example, are speaking from their hearts. Conversely "liturgical" churches find the depth and richness of their prayers which have been painstakingly written, to be preferable. But these assumptions are somewhat misleading. For example, one remarkable thing about the worship service at Saint Gregory's is that it feels so spontaneous. And yet it is actually highly scripted. In other words, it achieves what less liturgical churches often hope to achieve-a sense of openness, spontaneity, and lack of formality, and the sense that the Holy Spirit is alive and guiding the worship. But is does by very closely following a script, one that gets modified on the basis of...short meetings after each service. $(2013,140)$

As Benson notes, those that lead the liturgy at Saint Gregory's achieve this responsiveness to the Holy Spirit not by an instantaneous spontaneity (although we should not rule out that this might be another way of the Holy Spirit guiding worship), but rather, by a regular prayerful reflection on the practices of worship. So, whilst the Holy Spirit might play a kind of unseen mysterious role in uniting the acts of participants' worship, there are also practical ways in which a church, understood as a group agent, might include and be guided by the directions of the Holy Spirit in a way which sets such a group apart from any other social structure.

\section{Group-agency and inclusivity}

Finally, we are now in a position to see how the group-agency model handles cases of nonparadigm participation in a church's worship.

First, it is important to acknowledge that in order for a church to allow for a diverse group of individuals to count as being represented by the actions of the wider church community, it must have a diverse understanding of membership. If membership is restricted to only neuro-typical adults, then the actions of a church in worship will not be inclusive of anyone other than neuro-typical adults. For an account of group-agency to be inclusive, the Church must actively include those who are often excluded from worship. As Connor, writing about his friend Trey, who has learning difficulties, notes, '[o]nly the community that denies Trey baptism can claim that the learning impairment is his alone not the community's responsibility' (2012, 91). 
Secondly, assuming we adopt a diverse understanding of membership, we can see straightforwardly how an account of representative action has potential to include individuals into the worship of the Church who are not able to actively engage in those practices which require some kind of shared-agency. By belonging to a church as a member, a neuro-atypical individual can be represented in worship by those who take an active role, even if it is not possible for such an individual to take an active role herself. This seems particularlu relevant in the case of those with severe neurological impairments and very young infants. Wolterstorff (2012) makes a similar point in a political context of the importance of authorized action. He writes that, 'one form of governance of others takes is governance of those who are incapable of forming and carrying out a rational plan of action for themselves, small children and the "feebleminded" being the best examples. Someone has to govern them in their stead, on their behalf $(2012,54) .^{24}$

However, whilst this suggestion might provide what Timpe describes as integration, we are yet to see how worship might be inclusive in a way which gives rise to Church agency. Indeed, it is important to say more about how non-paradigm participants can contribute and engage in the church's worship. ${ }^{25}$

Whilst there is clearly much to be said in general about how non-paradigm participants can contribute to worship, as with my previous discussion, the focus here will be on how ASD individuals can contribute to worship. It is first important to note here that there are things which ASD individuals can contribute to worship which many neuro-typical individuals cannot. For instance, many individuals with ASD report to having a kind of heightened spiritual perception; Olga Bogdashina describes the experience of 'simply being' $(2013,192)$ which is reported by some individuals with ASD, a state of heightened perceptual awareness, and a peacefulness of being in the moment. As she goes on to note, this state of being which many autistic individuals report, also brings with it a heightened sense of spiritual awareness and an openness to certain kinds of religious experience (2013,197-198). Lamar Hardwick, a pastor who was diagnosed with ASD later in life, describes a different kind of spiritual experience which he

\footnotetext{
${ }^{24}$ Additionally, he writes, governance and authorized action is sometimes on behalf of those who are capable of 'forming and carrying out a rational plan of action. Governance in this case consists of the combination of someone issuing directives to another person and the recipient complying with these directives... to bring about what is judged to be some good' $(2012,54)$. ${ }^{25}$ Or, to put this point in another way, we need to see how non-paradigm participants get credit for engaging in worship, as an anonymous referee puts it.
} 
attributes, in part, to his autism; Hardwick writes that he is able to spend intense periods of time studying Scripture and first century history $(2017,114-15)$. Noticing these differences can help us to see individuals with ASD as those who can contribute to the worship of a church community. As Conner puts this point,

When we recognize that limitations in some capacities like verbal communication skills open up other avenues of discerning God's presence, then we might be more eager to engage other capacities for communing with God and others and for theological insight. $(2012,83)$.

For example, in the case of an individual with ASD who experiences a heightened spiritual awareness, such an individual might in turn lead other individuals in the congregation to a heightened awareness of the presence of God, and thereby, in turn, contribute to the collective actions of the group. It is important to see that just like many other social structures, actions which are the result of shared-agency are not the only kind of actions which contribute to the actions of a group. Just as an expert reporting to a government department or think tank might change the direction and beliefs of the government as a whole in making its members aware of something about their environment, certain neuro-atypical individuals might contribute to the worship of a church in ways which change the collective direction of a church's actions in worship. Yong (2007), in writing on how our ecclesiology can be renewed by considering the role of neuro-atypical individuals, writes that profoundly disabled individuals are able to 'become mentors who are inspired by the Spirit to reshape the gestures of the body of Christ' $(2007,224)$. Yong argues that if the Church is to be shaped by a Spirit of hospitality, then profoundly disabled individuals, who are constituent parts of the Church, have an important role to play in shaping the actions and beliefs of the wider body. The Church's ministry is not merely 'to' such individuals, Yong notes, but, rather, the Church must minister 'with' these individuals $(2007,224)$ as constituent parts of the same whole.

Thus, it seems entirely possible that individuals with ASD can and do contribute to worship. By considering the church as a group-agent, we are able to not only include nonparadigm participants, but also, we can see ways in which these individuals can get credit for their participation in a church's acting. In some cases of non-paradigm participation, individuals will intend for their worship to be united with the group, despite not being able to coordinate their actions in the way required for shared-agency. That is, if the context and culture of a particular church is inclusive and informative about non-paradigm participation, then all 
members of the congregation (including those who cannot form we-intentions) might be regarded as contributing an important part of the group's acting.

Yet, there are surely many other cases of non-paradigm participation which are less clear than this. The case of very young infants or those with severe ASD would appear to be more difficult to account for. Some individuals might not intend or be aware that their actions contribute to the group's acting, so we might wonder, how could such cases count as a part of the church's worship? To see how we might overcome this difficulty, it is important to return to the question of the group's structure and authorization conditions. Just as in the case of a ground level terrorist organization, the individuals might not be aware how their actions contribute to something wider, or even that they play a contributing role at all, churches can be structured in such a way as to authorize the actions of all of those who participate in the church's worship. The decision-making structures (hierarchical bodies, church councils, etc.) referred to in the previous section, have a vital role to play in recognizing and licensing the actions of those who are neuro-atypical as contributing to the worship of the Church as a group. Yet, if these structures or decision-making bodies do authorize individuals to act on behalf of the group, then there is no reason why even those who are not able to intentionally contribute, cannot be included as part of a church's group action.

As we noted in the previous section, whilst the church has similarities with many other cases of group action, one of the key differences lies in the role of the Holy Spirit. In a very practical sense, one of the roles of the Holy Spirit in an inclusive worshipping community might be to prompt those who are able to shape and direct the worship of the group to find ways of including and authorizing the actions of those who are often excluded by other groups in society. Whilst this might be through some mysterious, supernatural means, there might also be a concrete, practical outworking of the work of the Holy Spirit. Just as Benson reports St. Gregory's as reflecting on their liturgical patterns and submitting to the guidance of the Holy Spirit, those who are in positions of authority within a church community might seek the guidance of the Holy Spirit in helping them to be aware of how to include non-paradigm participants. There is clearly much more to be said on this issue, and this is where the work of the analytic theologian ends and reflective practitioners begins.

\section{Conclusion}

As I have stressed throughout, a shared-agency account and a group-agency account of group action are seeking to explain different phenomenon. One is not better than the other. Both kinds of group action are present in the worship of church congregations. However, it is also 
important to recognise the limitations of accounts of group action which exclude certain individuals from worship. A shared-agency account of group action is limited in what it can explain in relation to worship. By considering a church as a group agent, in which a diverse group of people can belong as members and contribute to the group's actions, we have much more scope to provide an inclusive model of Church action. As we have seen, such an approach to worship is not without its challenges. However, to take seriously the apostle Paul's command that the body of Christ is composed of those who are often seen as dishonourable or dispensable, is surely to take seriously the need for an inclusive model of Church action. ${ }^{26}$

\footnotetext{
${ }^{26}$ I would like to thank David Efird, Andrew Torrance and Alan Torrance, along with the editor and two anonymous referees for their helpful feedback on earlier drafts of this paper. Many thanks to the audience at the Logos Institute seminar at the University of St. Andrews for their insightful comments. I am also very grateful to the Templeton Religion Trust for their generous funding whilst writing this article.
} 


\section{References}

Bruce Ellis Benson, 2006. Liturgy as a Way of Life. Grand Rapids, Michigan: Baker Academic.

Olga Bogdashina. 2013. Autism and Spirituality. London: Jessica Kingsley Publishers.

Michael E. Bratman. 1999. Faces of Intention. Cambridge: Cambridge University Press.

Book of Common Prayer, According to the use of the Episcopal Church. 1979. New York: The Church Hymnal Corporation, New York.

Constanza Colombi, Kristin Liebal, Michael Tomasello, Gregor Young, Felix Warneken, and Sally J. Rogers. 2009. 'Examining Correlates of Cooperation in Autism'. Autism, 13.2, 143-163.

Common Worship: Services and Prayers for the Church of England. 2000. Church House Publishing.

Benjamin T. Conner. 2012. Amplifying Our Witness: Giving Voice to Adolescents with Developmental Disabilities. Grand Rapids/Cambridge: William B. Eerdmans.

Terence Cuneo. 2016. Ritualized Faith: Essays on the Philosophy of Liturgy. Oxford: Oxford University Press.

Peter French. 1995. Corporate Ethics. Orlando, FL: Harcourt Brace.

Margaret Gilbert. 1989. On Social Facts. London: Routledge.

Lamar Hardwick. 2017. I am Strong. Little Elm: eLectio Publishing.

Stanley Hauerwas. 1995. In Good Company: The Church as Polis. Notre Dame: University of Notre Dame Press.

Dru Johnson. 2016. Knowledge by Ritual: A Biblical Prolegomenon to Sacramental Theology. Winona Lake, Indiana: Eisenbrauns. 
Christian List, Christian Elsholtz, and Thomas D. Seeley. 2009. 'Independence and Interdependence in Collective Decision Making: An Agent-based Model of Nest-site Choice by Honey Bee Swarms'. Philosophical Transactions of the Royal Society B 364: 755-63.

Christian List, Christian and Philip Pettit. 2011. Group Agency. Oxford: Oxford University Press.

Ann Memmott. 2015. Welcoming Autistic People in our Churches and Communities. Diocese of Oxford, available at: http://www.oxford.anglican.org/wpcontent/uploads/2013/01/autism guidelines.pdf [accessed on 17/10/17].

Seamus Miller. 2001. Social Action: A Teleological Account. Cambridge: Cambridge University Press.

Barbara J. Newman. 2011. Autism and your Church. Grand Rapids: Friendship ministries. Revised and updated edition.

Alexander Schmemann. 1966. Introduction to Liturgical Theology. Crestwood, NY: St. Vladmir's Seminary Press.

John Searle. 1990. 'Collective Intentions and Actions'. In Consciousness and Language. Cambridge: Cambridge University Press. pp. 90-106

2010. Making the Social World: The Structure of Human Civilization. Oxford: Oxford University Press.

Thomas D. Seeley. 2001. 'Decision Making in Superorganisms: How Collective Wisdom Arises from the Poorly Informed Masses'. In Bound Rationality: The Adaptive Toolbook edited by Gerd Gigerenzer and Reinhard Selten. MIT Press.

James K.A. Smith. 2009. Desiring the Kingdom: Worship, Worldview, and Cultural Formation. Grand Rapids, Michigan: Baker Academic.

Kevin Timpe. 2017. 'Structuring Communities for Inclusion rather than Exclusion', Public Lecture, University of York, 6/11/2017, from: https://www.youtube.com/watch?v= ${ }_{\text {xvv0bfXJsZw }}$ [accessed on 25/10/2017]. 
Deborah Perron Tollefsen. 2015. Groups as Agents. (Cambridge: Polity Press)

Michael Tomasello, Malinda Carpenter, Josep Call, Tanya Behne, and Henrike Moll. 2005.

'Understanding and Sharing Intentions: The Origins of Cultural Cognition'. Behavioural and Brain Sciences, 28, 675-735.

Raimo Tuomela. 2013. Social Ontology: Collective Intentionality and Group Agents. Oxford: Oxford University Press.

Evelyn Underhill. 1936. Worship. London: Nisbet and Co, Ltd.

David J. Velleman, David J. 1989. Practical Reflection. Princeton: Princeton University Press.

J.J. von Allemen, 1965. Worship: Its Theology and Practice. London: Lutterwroth Press

Nicholas Wolterstorff. 2012. The Mighty and the Almighty. Cambridge: Cambridge University Press.

2015. The God We Worship: An Exploration of Liturgical Theology. William B. Eerdmans Publishing Company.

forthcoming, Acting Liturgically. Oxford: Oxford University Press.

NT. Wright. 2008. 'N.T. Wright on Word and Sacraments: Baptism'. Reformed Worship: Resources for Planning and Leading Worship, available online at:

https://www.reformedworship.org/article/december-2008/n-t-wright-word-and-sacramentsbaptism [accessed on 17/10/17].

Amos Yong. 2011. The Bible, Disability and the Church: A New Vision of the People of God. Grand Rapids, Michigan: William B. Eerdmans Publishing Company.

2007. Theology and Down Syndrome. Waco, Texas: Baylor University Press. 